\title{
CARACTERIZAÇÃO PRELIMINAR DO QUIMISMO DAS ÁGUAS SUBTERRÂNEAS EM CUIABÁ-MT
}

\author{
Lílian Fátima de Moura Apoitia*
}

\author{
DISSERTAÇÃO DE MESTRADO - Programa de Pós-Graduação em Geologia - UFPR \\ DATA DE DEFESA: 22 out. 2003
}

\begin{abstract}
O presente trabalho teve a finalidade de realizar uma distinção química das águas que circulam nas diferentes litofácies que compõem o Grupo Cuiabá, no município de Cuiabá-MT. Foram selecionados 12 pontos de amostragem, os quais foram julgados representativos das características hidrogeoquímica do aqüífero da região. O município de Cuiabá está situado sobre litologias deformadas pertencentes ao Grupo Cuiabá, as quais são constituídas por rochas de baixo grau de metamorfismo, tais como filitos, metarenitos e metarcóseos, com xistosidade bem desenvolvida e intensamente dobrada e fraturada. O potencial hídrico subterrâneo apresenta características de meio poroso e fraturado. As coletas foram realizadas nos dias $7,14,15 \mathrm{e}$ 31 de julho/2003. Os parâmetros analisados foram: $\mathrm{HCO}^{-3}$ (Bicarbonato), $\mathrm{CO}_{3}^{-2}$ (carbonato), $\mathrm{SO}_{4}^{-2}$ (sulfato),
\end{abstract}

$\mathrm{Cl}^{-}$(cloreto) $\mathrm{NO}_{3}^{-}$(nitrato), $\mathrm{PO}_{4}^{-3}$ (fosfato), $\mathrm{Ca}^{+2}$ (cálcio), $\mathrm{Mg}^{+2}$ (magnésio), $\mathrm{Na}^{+}$(sódio), $\mathrm{K}^{+}$(potássio), $\mathrm{Fe}$ (ferro total), turbidez, condutividade elétrica, sólidos totais e $\mathrm{pH}$. Os tipos hidroquímicos foram obtidos a partir da relação de miliequivalência entre os elementos principais, na forma de cátions e ânions, utilizando-se o diagrama triangular de Piper. Os resultados apresentados pelo Diagrama de Piper mostraram que as litofácies que compõem o Grupo Cuiabá em Cuiabá possuem um comportamento semelhante, onde $91,7 \%$ dos pontos analisados se caracterizam por águas bicarbona-tadas cálcicas e magnesianas, e 8,3\% se caracterizam por águas sulfetadas ou cloretadas sódicas. Uma avaliação analítica preliminar mostrou que em relação aos parâmetros físico-químicos analisados as águas subterrâneas em Cuiabá são de boa qualidade. 